\title{
Akuntabilitas, Transparansi Pemerintah Desa dan Pengelolaan Dana Desa
}

\author{
Nius Gwijangge ${ }^{1}$ \\ Fakultas Ekonomi dan Bisnis \\ Universitas Udayana, Indonesia
I Gusti Ayu Made Asri Dwija Putri ${ }^{3}$
Fakultas Ekonomi dan Bisnis
Universitas Udayana, Indonesia

I Ketut Jati ${ }^{2}$

Fakultas Ekonomi dan Bisnis

Universitas Udayana, Indonesia

\author{
Ni Gusti Putu Wirawati ${ }^{4}$ \\ Fakultas Ekonomi dan Bisnis \\ Universitas Udayana, Indonesia
}

Surel : niusgwijangge854@gmail.com

ABSTRAK

Penelitian ini bertujuan untuk menilai akuntabilitas dan transparansi pemerintah desa terhadap pengelolaan Dana Desa di desa Sembiran, kecamatan Tejakula, kabupaten Buleleng. Sampel yang digunakan sebanyak 127 yang terdiri dari kepala desa sekertaris desa Bendahara Badan Permusyawaratan Desa (BPD) sebagai perwakilan dari masyarakat serta kepala seksi, denagan Teknik probabalitiy sampling dengan metode prorporotionate stratifid ramandom sampiling. Pengumpulan data dilakukan melalui penyembaran kuesioner. Teknik analisis yang digunakan pada penelitian ini adalah analisis linier begada. Hasil penelitian menunjukkan bahwa pengelolaan dana desa di desa cukup baik untuk menerapkan prinsip dan aturan mengenai akuntabilitas prinsip transparansi, dan partisipasi dalam pengelolaan dana desa dilaksanakan baik dari sisi pemerintah desa maupun dari sisi masyarakat maka akan meningkat kan akuntabilitan pengelolaan dana desa itu.

Kata Kunci: Akuntabilitas; $\quad$ Transparansi; Partisipasi; Pengelolaan Dana Desa.

\section{Village Government Accountability, Transparency and Village Fund Management}

\section{ABSTRACT}

This study aims to assess the accountability and transparency of the village government towards the management of the Village Fund in Sembiran village, Tejakula sub-district, Buleleng district. The sample used was 127 consisting of the village chief secretary of the village treasurer, the Village Consultative Body (BPD) as representatives of the community as well as section heads, with a probability sampling technique with the prorporotionate stratifid ramandom screening method. Data collection was carried out through distributing questionnaires. The analysis technique used in this study is a linear analysis of begada. The results showed that the management of village funds in the village was good enough to apply the principles and rules regarding the accountability of the transparency principle, and participation in village fund management was carried out both from the side of the village government and from the community side so that the accountability of the management of village funds would increase.

Keywords: Accountability; Transparency; Participation; Village Fund Management.

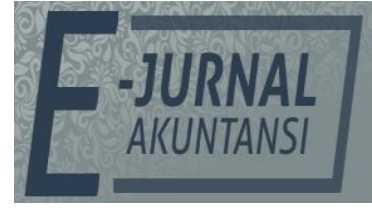

e-ISSN 2302-8556

Vol. 31 No. 6

Denpasar, Juni 2021

Hal. 1549-1560

DOI:

10.24843/EJA.2021.v31.i06.p16

PENGUTIPAN:

Gwijangge, N., Jati, I K., Putri, I G.A.N.A.D., \&

Wirawati, N.G.P. (2021).

Akuntabilitas,Transparansi

Pemerintah Desa dan

Pengelolaan Dana Desa. EJurnal Akuntansi, 31(6), 1549-

1560

RIWAYAT ARTIKEL:

Artikel Masuk:

10 Agustus 2020

Artikel Diterima:

20 Juni 2021

Artikel dapat diakses : https://ojs.unud.ac.id/index.php/Akuntansi/index 


\section{PENDAHULUAN}

Keberadaan desa secara yuridis dalam Undang-Undang No 6 tahun 2014 menjelaskan bahwa desa merupakan kesatuan masyarakat hukum yang memiliki batas wilayah yang mempunyai wewenang untuk mengatur dan mengurus urusan penyelenggaraan pemerintahan, pembangunan, dan kepentingan masyarakat setempat berdasarkan prakarsa masyarakat, hak asal usul, dan/atau hak tradisional yang diakui dan dihormati dalam sistem pemerintahan Negara Kesatuan Republik Indonesia (NKRI). Perubahan pemerintahan Indonesia secara desentralisasi dalam otonomi daerah mengakibatkan perubahan pada pola hubungan antara pemerintah pusat dan pemerintah daerah. Pola perubahan hubungan tersebut adalah perubahan wewenang dan tanggung jawab pemerintah di tingkat pusat maupun daerah. Namun demikian terdapat kewenangan yang tidak dapat di desentralisaikan dalam otonomi daerah, yaitu urusan politik luar negeri, pertahanan, keamanan, moneter dan fiskal, hukum, serta agama (Syamsudin, 2007:328) dalam (Astuty \& Fanida, 2013). Konsep desentralisasi dalam Undang-undang Nomor 32 Tahun 2004 tentang Pemerintah Daerah telah menunjuk tiga pola otonomi (Astuty \& Fanida, 2013). Pertama, otonomi provinsi sebagai otonomi terbatas. Kedua, otonomi kabupatan/kota sebagai otonomi luas. Ketiga, otonomi desa merupakan otonomi yang asli, bulat dan utuh serta bukan merupakan pemberian dari pemerintah sebaliknya pemerintah berkewajiban menghormati otonomi asli yang dimiliki oleh desa tersebut. Menurut Undang-undang No. 6 Tahun 2014, desa adalah kesatuan masyarakat hukum yang memiliki batas wilayah yang berwenang untuk mengatur dan mengurus urusan pemerintahan, kepentingan masyarakat setempat berdasarkan prakarsa masyarakat, hak asal usul, dan/atau hak tradisional yang diakui dan dihormati dalam sistem pemerintahan Negara Kesatuan Republik Indonesia.

Perwujudan akuntabilitas dapat dilakukan dengan menerapkan prinsipprinsipnya. Tujuan dari penerapan prinsip-prinsip tersebut agar pemerintah dapat meningkatkan kinerja secara efektif dan transparan didukung dengan komitmen yang kuat untuk melaksanakannya (Astuty \& Fanida, 2013). Pemerintah selaku pengelola dana publik agar dapat memenuhi akuntabilitas harus memperhatikan beberapa hal antara lain, anggaran, pengendalian akuntansi, dan sistem pelaporan (Suratmi et al., 2014).

Akuntabilitas dipengaruhi oleh pengetahuan aparatur desa mengenai sistem pelaporan yang baik sehingga dapat memantau dan mengendalikan kinerja dalam mengimplementasikan anggaran yang telah ditetapkan. Pemerintah sebagai pengelola keuangan memiliki kewajiban untuk menyampaikan informasi keuangan dan informasi lainnya yang akan digunakan untuk pengambilan keputusan ekonomi dan sosial secara transparan dan akuntabel. Sistem pelaporan merupakan laporan yang menggambarkan sistem pertanggungjawaban dari bawahan kepada atasan. Sistem pelaporan yang baik diperlukan agar dapat memantau dan mengendalikan kinerja manajer dalam mengimplementasikan anggaran yang telah ditetapkan. Pemerintah selaku pengelola dana publik harus mampu menyediakan informasi keuangan yang disajikan secara akurat, relevan, konsisten dan dapat dipercaya. Lembaga Administrasi Negara dan Badan Pengawas Keuangan dan Pembangunan BPKP 
mengemukakan laporan keuangan yang baik adalah laporan yang disusun secara objektif, jujur dan trasparan. Laporan umpan balik diperlukan untuk mengukur aktivitas-aktivitas yang dilaksanakan dalam rangka meningkatkan kinerja dan akuntabilitas pada pelaksanaan suatu rencana atau waktu mengimplementasikan suatu anggaran, sehingga manajemen dapat mengetahui hasil dari pelaksanaan rencana atau pencapaian sasaran anggaran yang telah ditetapkan.Partisipasi masyarakat merupakan salah satu faktor yang mempengaruhi keberhasilan dari program pembangunan maupun pengembangan masyarakat pedesaan termasuk akuntabilitas pengelolaan dana desa.

Hasil penelitian Hidayattullah \& Herdjiono, (2015) menunjukkan bahwa kejelasan sasaran anggaran berpengaruh positif signifikan pada akuntabilitas kinerja instansi pemerintah. Dengan adanya sasaran anggaran yang jelas maka akan mempermudah untuk mempertanggungjawabkan keberhasilan atau kegagalan pelaksanaan tugas organisasi. Hasil penelitian Hidayattullah \& Herdjiono, (2015) menunjukkan bahwa kejelasan sasaran anggaran berpengaruh signifikan pada kinerja manajerial. Hasil penelitian Zakiyudin \& Suyanto, (2015) menunjukkan bahwa kejelasan sasaran anggaran yang signifikan pada akuntabilitas kinerja instansi pemerintahan. Dalam penelitian Judarmita \& Supadmi, (2017) menunjukkan bahwa kejelasan sasaran anggaran yang positif pada akuntabilitas pengelolaan dana desa menyelenggarakan pemerintahannya sendiri, peneliti menganggap perlu adanya penelitian lebih lanjut agar dapat menjelaskan dinamika- dinamika yang ada secara harfiah ataupun ilmiah. Penelitian ini akan menganalisis implementasi pengelolaan dana desa dalam hal Akuntabilitas dan transparansi. Analisis difokuskan pada pengelolaan Dana Desa yang dilakukan oleh pemerintah desa. Penelitian ini bersifat studi kasus dengan mengambil objek penelitian Desa Sembiran Kecamatan Tejakula Kabupaten Buleleng yang berprestasi ditingkat kabupaten maupun nasional. Desa tersebut pun menjadi pemenang sebagai salah satu desa terbaik kategori nasional di Indonesia pada tahun 2014 dalam hal pemberdayaan masyarakat, pembangunan desa, inisiatif masyarakat dalam pemerintahan, pemahaman aparat dalam sistem informasi penyelenggaraan desa, dan kepatuhan terhadap kebijakan pemerintah. Berdasarkan latar belakang, peneliti akan melakukan penelitian guna untuk mendapatkan gambaran mengenai pengelolaan Dana Desa yang dilakukan oleh pemerintah desa dengan judul penelitian Akuntabilitas dan Transparansi Pemerintah Desa terhadap Pengelolaan Dana Desa.

Undang-Undang No 6 tahun 2014 tentang desa, merupakan UU tentang pengembalian tataran mengenai jati diri desa yang dikembalikan lagi kepada asal- usulnya. UU ini juga menggambarkan itikad negara untuk memberikan kemandirian kepada pemerintahan desa. Sehingga masyarakat desa disebut sebagai masyarakat yang mengatur dirinya sendiri dan membangun pemerintahan desa yang mengatur diri sendiri. Hal yang perlu diperhatikan, desa merupakan tatanan pemerintahan yang kecil di setiap daerah yang telah ada bahkan sebelum Indonesia ini terbentuk sebagai sebuah negara berdaulat. Reformasi ini untuk mendorong proses reformasi berbasis otonomi daerah bersifat hakiki. Tujuannya untuk menciptakan pemerintahan desa yang mampu 
menyejahterakan rakyat tataranbawah. Otonomi desa merupakan otonomi asli dan utuh yang dimiliki oleh desa, dan bukan termasuk pemberian dari pemerintah. Hak pemberian merupakan hak yang diperoleh atas dasar pemberian oleh pemerintahan yang mempunyai strata lebih tinggi.

Istilah governance menjadi sangat popular dan dijadikan sebagai kriteria pembangunan untuk negara-negara yang sedang berkembang. Istilah governance berbeda dengan istilah government yang hanya meliputi institusi-formal pemerintah dan birokrasi, maka istilah governance meliputi proses perencanaan yang dinamis untuk dapat mengelola manajemen pemerintahan, hubungan antar institusi dan organisasi di dalam pemerintahan, serta hubungan antara pemerintah dengan sektor publik. Dengan demikian governance merupakan proses untuk menyelenggarakan kekuasaan yang dimiliki oleh negara untuk melibatkan masyarakat dalam pengambilan keputusan (Prasojo \& Kurniawan, 2008).

Secara epistimologi birokrasi berasal dari gabungan kata "bureau" dan "kratia" yang berarti meja atau kantor dan pemerintahan. Awal mulanya, istilah ini digunakan untuk melihat suatu sistematika kegiatan kerja yang diperintah oleh suatu kantor melalui kegiatan-kegiatan admininistrasi. Pengertian birokrasi menurut (Weber et al., 1947) merupakan suatu organisasi dengan lingkup yang besar yang memiliki otoritas legal rasional, legitimasi, ada pembagia kerja dan bersifatimperasional.

Teori agensi adalah yang menjelaskan hubungan kontraktual antara principals dan agents. Pihak principals adalah pihak yang memberikan mandat kepada pihak lain, yaitu agents, untuk melakukan semua kegiatan atas nama principals dalam kapasitasnya sebagai pengambilan keputusan (Jensen \& Smith, 1984). Dalam organisasi sektor publik principals adalah rakyat dan agents adalah pemerintah dalam hal ini yaitu kepala desa dan aparat desa lainnya (Ismail et al., 2016).

Menurut Kamus Besar Bahasa Indonesia (KBBI), Akuntabilitas mempertanggungjawabkan pengelolaan sumber daya serta pelaksanaan kebijakan yang dipercayakan kepada entitas pelaporan dalam mencapai tujuan yang telah ditetapkan secara periodik. Menurut Suharto (2006) dalam (Ngongare et al., 2016) menyatakan akuntabilitas diartikan sebagai kemampuan menunjukkan catatan atau laporan yang bisa dipertanggungjawabkan. Sehingga akuntabilitas merupakan suatu bentuk pertangungjawaban untuk melaporkan dan menyajikan kegiatan-kegiatan yang telah dilaksanakan kepada pihak yang lebih atas.

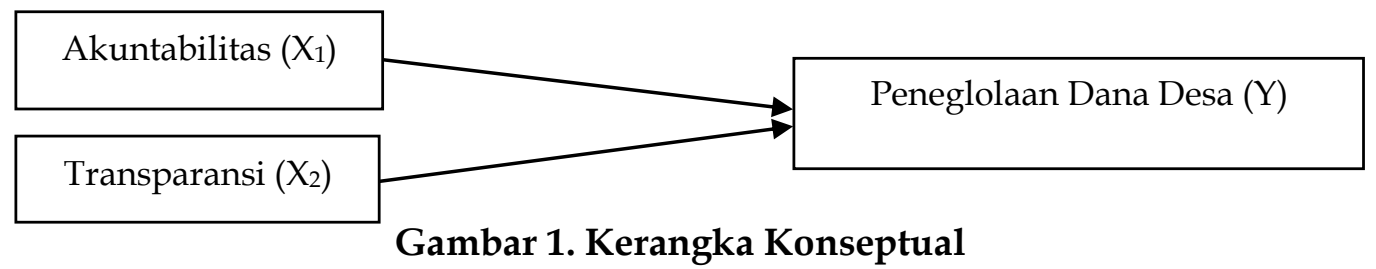

Sumber: Data Penelitian, 2019

Berdasarkan telah pustaka dan tujuan penelitian maka hipotesis yang dapat dibuat dalam penelitian ini sebagai berikut. 
Undang-undang tahun 2014 tentang Desa menyebutkan bahwa Desa adalah desa dan desa adat atau yang disebut dengan nama lain, selanjutnya disebut Desa, adalah kesatuan masyarakat hukum yang memiliki batas wilayah yang berwenang untuk mengatur dan mengurus urusan pemerintahan, kepentingan masyarakat setempat berdasarkan prakarsa.

$\mathrm{H}_{1}$ : Akuntabilitas pemerintah desa berpengaruh positif terhadap pengelolaan dana desa.

Transparansi pemerintah yaitu perwujudan kewajiban untuk mempertanggungjawabkan pengelolaan dan pengendalian sumber daya dan pelaksanaan kebijakan yang dipercayakan dalam rangka pencapaian tujuan yang telah ditetapkan. Asas akuntabel yang menentukan bahwa setiap kegiatan dan hasil akhir kegiatan penyelenggaraan pemerintahan desa harus dapat dipertanggungjawabkan kepada masyarakat desa sesuai dengan ketentuan peraturan perundang-undangan.

$\mathrm{H}_{2}$ : Transparansi pemerintah desa berpengaruh positif terhadap pengelolaan dana desa.

\section{METODE PENELITIAN}

Jenis data pada penelitian ini menguanakan data kuantitatif dan kualitatif. Data kualitatif yang digunakan dalam penelitian ini adalah gambaran umum Desa Senbiran serta data tentang responden seperti nama, jeniskelami latar belang pendidikan, lama bekerja dan jabatan dalam pemerintah Desa. Data kuantitatif yang digunakan penelitian ini adalah jawaban responden atas kuesioner yang digunakan dalam penelitian ini. Sumber data yang di gunakan dalam penelitian ini adalah data primer dan data sekunder. Data primer berupa jawaban responden mengenai pertanyaan kuesioner yang di sebarkan di desa Sembiran yang mendapat dana terbesar kabupaten buleleng dan kementerian pusat Data sekunder dalam penelitian ini yaitu data yang diperoleh dari koran digital pemerintah kabupaten Buleleng tentang pembinaan dana desa. Populasi dalam penelitian adalah satuan kinerja perangkat Desa Sembiran Keacamtan Tejakula Kabupaten Buleleng pada periode Tahun 2017-2019 yang berjumlah satuan 184 pemem Des Desa Sembiran Kecamtan Tejakula kabupaten Beleleng. Pengambilan sampel dalam penelitian ini dengan teknik probablitiy sampiling proportisonate stratified romadom sampiling. Sampel dalam penelitian ini sebanyak 127responden di Desa Sembiran.

Akuntabilitas dapat dinilai berdasarkan latar belakang pendidikan serta pelatihan Wahyudi, (2017) oleh perangkat desa dalam kaitannya akutabilitas dia dopsi dari Wahyudi, (2017) yang terdiri dari atas tahap perencanaan, tahap pelaksanaan, tahap perubahan APBDES, tahap penatausahaan, tahap pelaporan, tahap pertanggungjawaban.

Transparansi adalah prinsip keterbukaan yang memungkinkan masyarakat untuk mengetahui dan mendapatkan akses informasi seluas-luasnya tentang pemerintha desa terhadap pengelolaankeuangandana desa. Instrumen system penelolaan keuanagan dana Desa diadopsi dari penelitian (Arta \& Rasmini, 2019) dan (Dewi \& Gayatri, 2019). Sudah dilakukan modifikasi oleh peneliti yang sediri dari 6 pertanyaan yang di ukur dengan indikator, yaitu perumusan perencanaan, pelaksanan, penatausahaan, pelaporan, petanggujawaban, dan pembina dan pengawasan. 
Dana Desa adalah dana APBN bagi Desa, ditransfer melalui APBD kabupaten/kota. Dana Desa digunakan untuk membiayai penyelenggaraan pemerintahan, pelaksanaan pembangunan, pembinaan kemasyarakatan, dan pemberdayaan masyarakat. Instrumen system penelolaan keuanagan dana Desa diadopsi dari penelitian (Arta \& Rasmini, 2019) dan (Dewi \& Gayatri, 2019). Sudah dilakukan modifikasi oleh peneliti yang sediri dari 6 pertanyaan yang di ukur dengan indikator, yaitu perumusan perencanaan, pelaksanan, penatausahaan, pelaporan, petanggujawaban, dan pembina dan pengawasan.

Data dalam penelitian ini dikumpulkan melaluai penyembaran insturumen penelitian berupa kuesioner. Penyembaran kuesioner dilakukan secara lasung oleh peneliti ke kantor Desa Sembiran kuesioner merupakan teknik pengumpualan data yang dilakukan dengan secara memberi seperangkat pertanyaan atau pertanyaan tertulis kepada responden.

Dalam menguji hipotesis penelitian ini, menggunakan analisis data dimulai dengan uji validitas, uji reliabilitas, statistik deskriptif, uji asumsi klasik (uji normalitas, multikolinearitas, dan heteroskedastisitas), dan uji analisis regresi berganda dan pengujian hipotesis. Analisis Regresi Linier Berganda digunakan dalam penelitian ini untuk menguji hipotesis dengan persamaan berikut.

$$
\begin{aligned}
& Y=a+\beta 1 X 1+\beta 2 X 2+X 2+\varepsilon \\
& \text { Dimana: } \\
& \mathrm{Y} \quad=\text { Pengelolaan dana Desa } \\
& \text { a = Nilai konstanta } \\
& \mathrm{X}_{1}=\text { Aksesibilitas } \\
& \mathrm{X}_{2} \quad=\text { Trans paransi } \\
& \mathrm{B}_{1} \beta_{2}=\text { Koefisien Regresi linier } \\
& \varepsilon \quad=\text { Error }
\end{aligned}
$$

\section{HASIL DAN PEMBAHASAN}

Desa Sembiran merupakan sebuah desa kuno yang sudah berumur ratusan tahun. Ada banyak peninggalan bersejarah di desa ini yang diyakini sudah berusia 2.000 tahun sebelum masehi. Ada setidaknya 40 perabotan kuno yang dibuat dari batu dan besi yang ditemukan di Sembiran yangkemudian dikelompokkan menjadi jenis perabotan berbentuk pipih dari besi, kapak tangan dari batu, alat pemotong persegi dari batu, palu yang terbuat dari batu, dan serpihan beberapa perabot dari batu.

Selain ditemukan sekitar 40 perabotan kuno dan bersejarah tersebut, juga ditemukan sekitar 20 prasasti perunggu yang menceritakan sejarah desa ini. Berbagai benda peninggalan tersebut mesti dijaga dan dilestarikan dengan sebaik-baiknya sehingga karena alasan itulah maka kemudian dibangun kembali sebuah rumah tua yang sesuai dengan bentuk aslinya, yang biaya nya ditanggung oleh pemerintahan kabupaten dengan maksud untuk melindungi berbagai penemuan tersebut. Selain ada rumah tua yang unik dan menarik, desa ini juga memiliki potensi seni serta adat-istiadat yang masih dipertahankan sampai kini. Beberapa tarian sakral masih dipentaskan dalam upacara-upacara tertentu sebagai perwujudan bahwa kesenian tradisional warisan nenek moyang masih terus diupayakan untun dipertahankan baik itu dalam konteks lingkungan keluarga maupun masyarakat. 
Data kakteristik responden adalah data responden yang dikumpulan untuk mengetahui profil penelitian. Berdasarkan hasil penelitian yang dilakukan terhadap perangkat desa diDesa Sembiran dapatdiketahui karakteristik responden nya meliputi jenis kelamin, usia,pendidikan terakhir dan masa pekerjaan yang dijelaskan pada Tabel 1.

Tabel 1. Karakteristik Demografi Responden di DesaSembiran

\begin{tabular}{|c|c|c|c|c|}
\hline No. & Variabel & Klasifikasi & $\begin{array}{l}\text { Jumlah } \\
\text { (orang) }\end{array}$ & $\begin{array}{c}\text { Persentase } \\
(\%)\end{array}$ \\
\hline \multirow[t]{3}{*}{1.} & Jenis kelamin & Laki-laki & 85 & 67,46 \\
\hline & & Perempuan & 42 & 32,54 \\
\hline & & Jumlah & 127 & 100 \\
\hline \multirow[t]{5}{*}{2.} & Usia & 20-30Tahun & 14 & 11,11 \\
\hline & & 31-40Tahun & 20 & 315,87 \\
\hline & & 41-50Tahun & 40 & 31,75 \\
\hline & & $>50$ Tahun & 53 & 41,27 \\
\hline & & Jumlah & 127 & 100 \\
\hline \multirow[t]{5}{*}{3} & Pendidikan Terakhir & SMA & 52 & 41,27 \\
\hline & & Diploma & 3 & 1,89 \\
\hline & & S1 & 70 & 55,56 \\
\hline & & S2 & 2 & 1,89 \\
\hline & & Jumlah & 127 & 100 \\
\hline \multirow[t]{5}{*}{4.} & MassaPekerjaan & 1 Tahun & 20 & 15,85 \\
\hline & & 2 Tahun & 25 & $19^{\prime} 84$ \\
\hline & & 3 Tahun & 6 & 4,76 \\
\hline & & 4 Tahun & 76 & 59,52 \\
\hline & & Jumlah & 127 & 100 \\
\hline
\end{tabular}

Sumber: Data Penelitian, 2019

Berdasarkan Tabel 1, menujukan jumlah aparatur desa di Desa Sembiran Kecamtan Tejakula Kabupaten Buleleng yang dijadikan sampel sebanyak 127 orang. Jika di lihat dari jenis kelamin jenis kelamin laki-laki komunitas dalam peneltian dengan persensate sebesar 6,4 persen jika di dilihat dari usia yang memiliki usia >50 Tahun mendominasi dengan peresentase sebesar 41,27 jika dilihat dari tingkatpendidikan yang memiliki tingakat pendidikan terakhir S1 yang mendominasi dengan peresentase sebesar 55,65 persen dengan masa pekejaan yang mendominasi dengan persentase sebesar 59,52 persen.

Tejakula kabupataen Buleleng yaitu, sekertaris Desa bendahara, kasi sejahteraan kaur keuangan, kaur umum, kaur pencanaan, kasi pelyanan dan kepala wilayah/dusun. Berdasarkan ringkasan pengiriman dan pengambilan kuesioner dapat diketahui jumlah kuesioner yang disebar sebanyak 132 kuesioner, dan kuesioner yang kembali sebanyak 127 kuesioner sedangkan kuesioner yang tidak di kembalikan sebanyak 5 kuesioner hingga banyak kuesioner yang digunakan adalah sebanyak 127 kuesioner.

Uji validitas yang dilakukan dengan mengkorelasikan antara skor faktor dengan skor total dan bila dikorelasi tiap faKtor tersebut bernilai positip $(\mathrm{r}>0,5$ maka instrument penelitian tersebut dapat dikatan valid. Instrumen yang valid adalah. Hasil uji validitas penelitian ini di ditunjukan dalam Tabel 1. 
Tabel 2, menunjukan bahwa seluruh koefisien korelasi dari indikator variabel di uji nilai lebih besar dari 0,05 ( $\mathrm{r}>0,05)$. Hasil tersebut menujukan bahwa seluh seluruh indikator yang dapat pada penelitian ini dibukti valid.

Tabel 2. Hasil Uji Validitas

\begin{tabular}{|c|c|c|c|c|}
\hline No & Variabel & Indikator & $\mathrm{r}$ & keterangan \\
\hline \multirow[t]{8}{*}{1} & Akuntabilitas & X1.1 & 0,679 & Valid \\
\hline & & $\mathrm{X} 1.2$ & 0,730 & Valid \\
\hline & & $\mathrm{X} 1.3$ & 0,837 & Valid \\
\hline & & X1.4 & 0,624 & Valid \\
\hline & & $\mathrm{X} 1,5$ & 0,715 & Valid \\
\hline & & X1.6 & 0,845 & Valid \\
\hline & & $\mathrm{X} 1.7$ & 0,876 & Valid \\
\hline & & X1.8 & 0,733 & Valid \\
\hline \multirow[t]{5}{*}{2} & Transparansi & X2.1 & 0,666 & Valid \\
\hline & & $\mathrm{X} 2.2$ & 0,906 & Valid \\
\hline & & $X 2.3$ & 0,749 & Valid \\
\hline & & $\mathrm{X} 2.4$ & 0,778 & Valid \\
\hline & & $X 2.5$ & 0,811 & Valid \\
\hline \multirow[t]{10}{*}{3} & Pengelolaan Dana & Y1.1 & 0,723 & Valid \\
\hline & Desa & Y1.2 & 0,723 & Valid \\
\hline & & Y1.3 & 0,846 & Valid \\
\hline & & Y1.4 & 0,801 & Vaild \\
\hline & & Y1.5 & 0,750 & Valid \\
\hline & & Y1.6 & 0,831 & Valid \\
\hline & & Y1.7 & 0,809 & Valid \\
\hline & & Y1.8 & 0,809 & Valid \\
\hline & & Y1.9 & 0,783 & Valid \\
\hline & & Y1.10 & 0,853 & Valid \\
\hline
\end{tabular}

Sumber: Data Penelitian, 2019

Uji reabilitas digunakan untuk unutuk mengukur konsistensi atau vaeiabel pada penelitian. Intrumen dikatakan reliabel unuk mengukur variabel bila memiliki nilaiCronbach Alpa $>0,60$. Hasil penelitian ini di tunjukan dalam Tabel 3.

Tabel 3. Hasil Uji Reabilitas

\begin{tabular}{lcc}
\hline \multicolumn{1}{c}{ Variabel } & Cronbach, $s$ & Keterangan \\
\hline Akuntabilitas (X1) & 0,894 & Reabilitas \\
Transparansi (X2) & 0,840 & Reabilitas \\
Pengelolaan dana desa (Y) & 0,939 & Rebilitas \\
\hline
\end{tabular}

Sumber: Data Penelitian, 2019

Tabel 3, menujukkan masing-masing Cronbach's Alpha pada tiap intrumen tersebut lebih besar dari 0,6 (Cronbach's Alpha > 0,6). Hasil tersebut menunjukan bahwa semua instrument reliabel sehinggadapat digunakan untuk melakukan penelitian.

Model analisis regresi linier bergada digunakan untuk mendapatkam koefisien regresi yang akan medapatkan apkah hipotesis yang akan dibuat atau ditolak. Hasil analisis ini mengacu pada hasil variabel Akuntabilitas $\left(X_{1}\right)$ variabel Transparansi $\left(\mathrm{X}_{2}\right)$, terhadap akuntabilitas pengelolaan dana Desa $(\mathrm{Y})$, di Desa Sembiran. Adapunhasil analisis regresi dengan program Stastistical Pacage of Social Science (SPSS) versi 21.0 for windows dapat dilihat pada Tabel 4. 
Berdasarkan Tabel 4, dapat ditulis persamaan regresi linier begada sebagi berikut.

$$
Y=4,72+0,509 X 1+0,987 \times 2+\varepsilon
$$

Tabel 4. Hasil Analisis Regresi Linier Bergada

\begin{tabular}{lccccc}
\hline & \multicolumn{2}{c}{$\begin{array}{c}\text { Unstandardized } \\
\text { Coefficients }\end{array}$} & $\begin{array}{c}\text { Standardized } \\
\text { Coefficiencts }\end{array}$ & T & Sig. \\
\cline { 2 - 4 } \multicolumn{1}{c}{ Model } & $\mathrm{B}$ & Std. Error & Beta & & \\
\hline (Constant) & 4,072 & 1,718 & & 2,370 & 0,019 \\
Akuntablitas & 0,509 & 0,083 & 0,413 & 6,162 & 0,000 \\
Transparansi & 0,897 & 0,123 & 0,489 & 7,287 & 0,000 \\
\hline
\end{tabular}

Sumber: Data Penelitian, 2019

Persamaan regresi linier bergada tertebut menunjukan bahwa nilai konstanta (a) menunjukan besar nya nilai variabel denpenden apabila nilai indenpenden adalah 0 (nol). Nilai konstanta sebesar 4,072 menunjukan besarnya pengelolaan dana desa adalah sebesar 4,072 apabilah akuntabilitas dan transparansi adalah 0 (nol) dengan nilai signifikansi $>0,05$. Nilai koefisien akuntabilitas (X1) 0,59 menunjukan trasparansi bertambah sebesar 1 satuan dari nili pengelolaan dana Desa (Y) akan mengalami kenaikan sebesar 0,509 satuan dengan asumsi variabel bebas lain nya konstan. Nilai koefisien Transparansi (X2) 0,897 menunjukan akuntablitas (X2) bertambah sebesar 1 satuan maka nilai dari pengelolaan dana Desa (Y) akan mengalami kenaikan sebesar 0,897 satuan dengan asumsi variavel bebas lainya konstan.

Tabel 5. Uji Normalitas (One Sample Kolmogorov-smirnov)

\begin{tabular}{lc}
\hline & Unstandardized Residual \\
\hline $\mathrm{N}$ & 127 \\
Kolmogorov-smirnov Z & 0,72 \\
Asymp. Sig (2-tailed) & 0,236 \\
\hline
\end{tabular}

Sumber: Data Penelitian, 2020

Berdasarkan dengan uji normalitas dengan menggunakan one sample Kolmogorov-smirnov menunjukkan bahwa besarnya nilai Kolmogorov-smirnov adalah sebesar 0,236. Sehingga dapat ditimpulkan bahwa model memenuhi asumsi nomalitas.

Tabel 6. Uji Multikolinieritas (Tolerance dan Variance Inflation Factor)

\begin{tabular}{lcc}
\hline \multirow{2}{*}{ Variabel } & \multicolumn{2}{c}{ Collinearty stastistc } \\
\cline { 2 - 3 } & Tolerance & VIF \\
\hline Akuntabilitas & 0,610 & 1,640 \\
Trans paransi & 0,610 & 1,640 \\
\hline
\end{tabular}

Sumber: Data Penelitian, 2020

Berdasar kan Tabel 6, tersebut ditunjukan bahwa tidak terdapat variabel bebas yang dimiliki nilai tolerance kurang dari 0,10 dan nilai VIF lebih dari 10, sehingga model regresi bebas dari gejala multikolineartas.

Berdasarkan Tabel 7, menunjukkan bahwa masing-masing model memiliki nilai signifikansi lebih besar dari 5 persen atau 0,05 sehingga dikatakan bebas dari gejala heteroskedastisitas.

Berdasarkan hasil Uji Heteroskedastissitas (Uji Gelesjer) diketahui bahwa nilai $R^{2}=66,2$ persen, yangberarti bawah sebesar 66,2 persen pengelolaan dana 
desa di Desa Sembiran di mengetahui oleh variabel akuntabilits $\left(X_{1}\right)$ transparansi $\left(\mathrm{X}_{2}\right)$ dan sisanya sebesar 33,8 persen di ketahui oleh variabel lain yang tidak diteliti pada penetian ini.

Tabel 7. Uji Heteroskedastissitas (Uji Gelesjer)

\begin{tabular}{lcc}
\hline \multicolumn{1}{c}{ Variabel } & T & Sig \\
\hline Akutabilitas & $-0,408$ & 0,684 \\
Transparansi & $-1,594$ & 0,114 \\
\hline
\end{tabular}

Sumber: Data Penelitian, 2020

Berdasarkan hasil analisis diketahui nilai signifikakansi $\mathrm{F}$ adalah 0,000< 0,05 , maka Ho ditolak. Hal ini berarti bahwa variabel akuntabilitas $\left(X_{1}\right)$ Variabel Transparansi $\left(\mathrm{X}_{2}\right)$ secara smultan signifikan terhadap pengelolaan keuangandana Desa $(Y)$ di desa Sembiran, atau model yang digunakan dalam penelitian ini layak dan dapat digunakan untuk analisis berikutnya.

Berdasarkan pengolahan data SPSS dihasilakan tingkat tingkat signifikansi $0,000<0,05$ dengan koefisien nya sebesar 0,509 berdasarkan nilai pengujian tersebut, dapat dilihat bahawa uji jatuh pada penolakan $\mathrm{H}_{0}$ ditolak dan $\mathrm{H}_{1}$ diterima hipotesis pertama. Hal tertebut dinyatakan bahwa terdapat positif signifikan antara akuntblitas terhadap pengelolaan dana desa di desa Sembiran. Apabila akuntabilitas mengkat maka pengelolaan dana desa akan meningkat sebesar 0,509. Dalam pengelolaan dana desa, pemerintah desa harus yang memiliki akuntabelitas yang dilihat dari latarbelaang pendidikan, pengamalaman mengikuti pelatihan, mengerti tentang akuntansi dana desa serta memahami peraturan dan prosedur mengenai penngelolaan dana desa beserta tujuan dana tersebut diberikan oleh pemerintah.

Hasil ini sesuai dengan good governance yang menjelaskan pemeriatah desa bertindak sebagai stewards, yang menerima bertanggungjawab untuk mengelolaan dana desa yang dikucurkan oleh pemerintah pusat untuk kepentinagan desa. Sebagai stewards, maka pemerrintah desa harus mengupayakan akuntabilitas dalam penyelenggaraan desa, pengelolaan keuangan desa perlu diselenggarakan sesuai dengan asas-asas pengelolaan dengan kompetensi yang mempunyai ,memahami tugas pokok, perencanaan dan penganggaran keuangan desa serta mampu menyusun laporan keuangan desa serta memenuhi norma aturan-aturan yang berlaku yang didukung dengan pengetahuan, kemampuan pelatihan, ketampilan dan kerjasama akuntablitas yang pada penelitian ini adalah aparatur desa yang baik maka semakin tinggi akuntablitas pengelolaan dana desa.hasil penelitian ini sesuaidengan penelitian yang dilakkan oleh Dewi \& Gayatri, (2019) nyatakan bawah kompetensi aparatur pengaruh postif terhadap akuntabilitas pengelolaan dana desa.

Berdasarkan pengolahan data SPSS dihasilakan tingkat tingkat signifikansi 0,000 <0,05 dengan koefisien nya sebesar 0,897 berdasarkan nilai pengujian tersebut, dapat dilihat bahawa uji jatuh pada penolakan $\mathrm{H}_{0}$ ditolak dan $\mathrm{H}_{1}$ diterima hipotesis kedua. Hal tertebut dinyatakan bahwa terdapat positif signifikan antara akuntblitas terhadap pengelolaan dana desa di desa Sembiran. Apabila akuntabilitas meningkat maka pengelolaan dana desa akan meningkat sebesar 0,897. Pemanfaatkan teknologi informasi Dalam organisasi desa akan membantu desa dalam melaksanakan tata kelola keuangan desa secara efisien. Hasil ini sesuai dengan good governance yang menjelaskan pemeriatah desa 
bertindak sebagai stewards, yang menerima bertanggungjawab untuk mengelolaan dana desa yang dikucurkan oleh pemerintah pusat untuk kepentinagan desa dengan pemanfaatkan teknogoli informasi yaitu system keuangan desa (SISKEUDES) ini merupakan salah satu teknologi informasi yang dilakukan oleh kemendagri bersama BPKP yang diharapkan bisa memperoleh kemudahan dan kesederhanaan dalam pengelolaan dana desa. Hasil Penelitian ini sesuai dengan penelitian yang dilakukan Abdullah \& Samad, (2019) menyatakan bahwa system keuangan desa belum positif terhadap pennyelenggaraan pemerintahan di Desa Tokaka. Penelitian Gayatri \& Latrini (2018) menyatakan bahwa penerapan SISKEUDES efektif terhadap kualitas laporan keuangan dana desa dan penelitian Sulina et al., (2017) juga mentatakan bahwa SISKEUDES pengaruh positif terhadap kinerjapemerintah desa di Desa Kaba-Kaba.

\section{SIMPULAN}

Berdasarkan hasil analisis diperoleh kesimpulan yaitu dalam pengelolaan terdapat signifikan pada Akuntabilitas Pengelolaan dana desa di desa Sembiran Hal ini semakin tinggi nya kompotensi maka akan meningkat kan akuntabilitas pengelolaan dana desa. Terdapat pergaruh positif dan signifikan antara transparani pengelolaan dana desa pada akuntabilitas pengelolaan dana desa di desa Sembiran. Hal ini berarti semaikin tingginya transparansi pengelolaan dana desa pada akuntabilitas pengelolaan dana desa.

Saran yang dapat diajukan berdasarkan hasil analisis adalah akuntalititas dan transparansi pengelolaan dana desa hendak nya ditingakan sehingga pemerintah desa yang sangat baik dapat terlaksana rerutam dalam memberikan pelayanan kepada masyarakat dan harus cepat dalam memjalankan tetiap keluan public. Pelaksanaan pemerintah yang baik perlu adanya akuntabilitas dan transparansi dalam pengelolaan Alokasi Dana Desa. Akuntabilitas dan transparansi bermanfaat bagi aparatur desa maupun desa, jika tidak ada akuntabilitas dan transparansi maka informasi regulasi dan alokasi dana hanya diketahui oleh aparat desa. Pemerintahan yang tidak transparan dan akuntabel akan menimbulkan kecurigaan dan ketidakpercayaan masyarakat terhadap pemerintah desa menyebabkan masyarakat kurang simpati terhadap program desa, sehingga program pembangunan desa tidak dapat berjalan.

\section{REFERENSI}

Abdullah, M. H., \& Samad, A. (2019). Pengaruh Sistem Informasi Keuangan Desa (SISKEUDES) Terhadap Kinerja Kepala Desa (Studi Kasus Desa Tokaka, Kecamatan Gane Barat Utara, Kabupaten Halmahera Selatan ). IJIS Indonesian Journal On Information System, 4(1), 13-24. https://doi.org/10.36549/ijis.v4i1.50

Arta, I. M. A. S., \& Rasmini, N. K. (2019). Pengaruh Kejelasan Sasaran Anggaran, Sistem Pelaporan dan Partisipasi Masyarakat Pada Akuntabilitas Pengelolaan Dana Desa. E-Jurnal Akuntansi, 26(1), 709-735. https://doi.org/10.24843/EJA.2019.v26.i01.p26

Astuty, E., \& Fanida, E. H. (2013). Akuntabilitas Pemerintah Desa Dalam Pengelolaan Anggaran Pendapatan Dan Belanja Desa (APBDES) (Studi Pada 
Alokasi Dana Desa Tahun Anggaran 2011 Di Desa Sareng Kecamatan Geger Kabupaten Madiun). Publika, 1(2).

Dewi, N. K. A. J. P., \& Gayatri. (2019). Faktor-Faktor Yang Berpengaruh Pada Akuntabilitas Pengelolaan Dana Desa. E-Jurnal Akuntansi, 26(2), 1269-1298. https://doi.org/10.24843/EJA.2019.v26.i02.p16

Hidayattullah, A., \& Herdjiono, I. (2015). Pengaruh Kejelasan Sasaran Anggaran, Pengendalian Akuntansi, Sistem Pelaporan Terhadap Akuntabilitas Kinerja Skpd Di Merauke. Prosiding Seminar Nasional Multi Disiplin Ilmu E Call For Papers UNISBANK (SENDI_U).

Ismail, M., Widagdo, A. K., \& Widodo, A. (2016). Sistem Akuntansi Pengelolaan Dana Desa. Jurnal Ekonomi Dan Bisnis, 19(2), 323-340.

Jensen, M. C., \& Smith, C. W. (1984). The Theory of Corporate Finance: A Historical Overview. https://doi.org/10.2139/ssrn.244161

Judarmita, N., \& Supadmi, N. L. (2017). Pengaruh Kejelasan Sasaran Anggaran, Sistem Pelaporan dan Audit Kinerja Pada Akuntabilitas Pengelolaan Dana Desa. E-Jurnal Akuntansi, 21(3), 1719-1746. https://doi.org/10.24843/EJA.2017.v21.i03.p01

Ngongare, Y., Mantiri, M. S., \& Kairupan, J. (2016). Akuntabilitas Pengelolaan Anggaran Dana Desa Dalam Pembangunan Infrastrukturdi Desa Kokoleh Satu Kecamatan Likupang Selatan. JURNAL EKSEKUTIF, 1(8). https://ejournal.unsrat.ac.id/index.php/jurnaleksekutif/issue/archive

Prasojo, E., \& Kurniawan, T. (2008). Prasodjo, Eko dan Kurniawan, Teguh. (2008) Reformasi Birokrasi dan Good Governance: Kasus Best Practices dari Sejumlah Daerah di Indonesia. Jurnal FISIP Universitas Indonesia. Hlm. 2-9. The 5 Th International Symposium of Jurnal Antropologi Indonesia, Banjarmasin., $1-15$.

Sulina, I. G. A. T., Wahyuni, M. A., \& Kurniawan, P. S. (2017). Peranan Sistem Keuangan Desa (Siskeudes) terhadap Kinerja Pemerintah Desa (Studi Kasus di Desa Kaba-kaba, Kecamatan Kediri, Kabupaten Tabanan). Jurnal Ilmiah Mahasiswa Akuntansi Undiksha, 8(2). https://doi.org/10.23887/jimat.v8i2.13197

Suratmi, N. M., Herawati, N. T., \& Darmawan, N. A. S. (2014). Pengaruh Audit Kinerja, Penyajian Laporan Keuangan, Dan Aksesibilitas Laporan Keuangan Terhadap Akuntabilitas Publik. Jurnal Ilmiah Mahasiswa Akuntansi Undiksha, 2(1). https:// doi.org/10.23887/jimat.v2i1.2882

Wahyudi, A. (2017). Akuntabilitas Pengelolaan Keuangan Desa di Kecamatan Unter Iwes Kabupaten Sumbawa. Universitas Mataram.

Weber, M., Henderson, A. M., \& Talcott, P. (1947). The Theory of Social and Economic Organization. New York, Oxford University Press.

Zakiyudin, M. A., \& Suyanto, S. (2015). Kejelasan Sasaran Anggaran, Pengendalian Akuntansi, Sistem Pelaporan dan Akuntabilitas Kinerja Instansi Pemerintah pada Inspektorat Jenderal Kementerian Agama RI. Jurnal Riset Akuntansi Dan Perpajakan, 2(1), 89-96. https://doi.org/10.35838/jrap.2015.002.01.8 